\title{
Surgical management of a rare case of inverted intranasal mesiodens
}

\author{
Melwin Mathew, ${ }^{1}$ Prem Sasikumar, ${ }^{2}$ Vijayaraghavan Jayashree Vivek, ${ }^{3}$ Revathy Kala ${ }^{4}$
}

'Periodontics, Melaka Manipal Medical College, Bukit Baru, Melaka, Malaysia

${ }^{2}$ Oral And Maxillofacial Surgery, Mahe Institute of Dental Sciences, Mahe, Puducherry, India

${ }^{3}$ Endodontics, Mahe Institute of Dental Sciences, Mahe, Puducherry, India ${ }^{4}$ Oral Pathaology, Government Dental College, Kottayam, Kerala, India

Correspondence to Dr Melwin Mathew: drmelwinmathew@gmail.com

Accepted 13 October 2020

\section{DESCRIPTION}

A 20-year-old female patient had reported for orthodontic treatment, and during the routine radiographical investigations, it was noticed that a mesiodens was impacted in the lower nasal floor. On further clinical examination, the tip of the mesiodens was clinically visible on the floor of the nose through the left nostril. Furthermore, the patient mentioned a history of recurrent rhinitis and sinusitis, and was not under any medication thinking that it was of allergic origin (figure 1).

Aetiology of an intranasal tooth is still not clear, but few factors play a key role in its occurrence: (1) genetic predisposition, (2) tooth displacement by trauma or pathosis, (3) supernumerary teeth developing from the dental lamina near the permanent tooth bud or from a permanent bud itself and (4) developmental disturbances like cleft lip and palate. ${ }^{12}$ The prevalence of its occurrence is $0.1 \%$ in the general population and $0.48 \%$ in association with cleft lip and palate. ${ }^{3}$

Determining the position of the mesiodens was done using a CT scan (figure 1) which revealed the palatally placed root. Access through the nostrils was challenging as it is difficult to grasp or luxate the impacted supernumerary tooth intranasally. As the overlying palatal shelf of bone was acceptably thin, the surgical plan was to approach the root intraorally through the palatal side and achieve adequate luxation of tooth orally. Once the tooth is luxated, the mesiodens will be grasped and

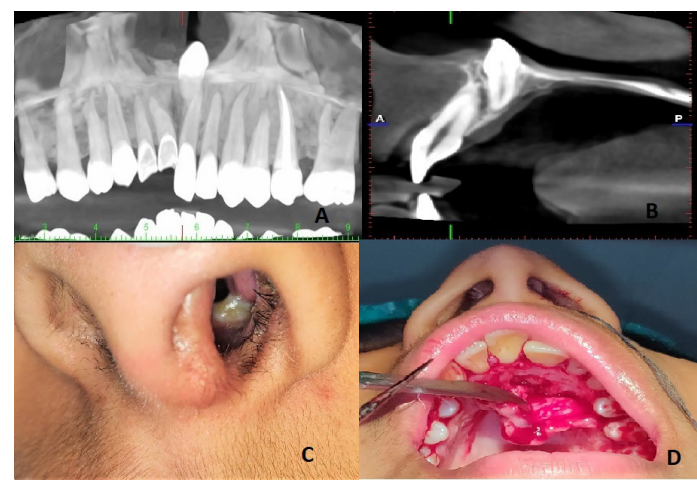

Figure 1 (A) Preoperative CT frontal view of the inverted intranasal mesiodens showing penetration into the nasal cavity. (B) Preoperative CT sagittal view showing the inverted intranasal mesiodens extending into the nasal cavity. (C) Inverted intranasal mesiodens clinically visible through the left nostrils. (D) Palatal approach of the intransal mesiodens for luxation of the tooth.

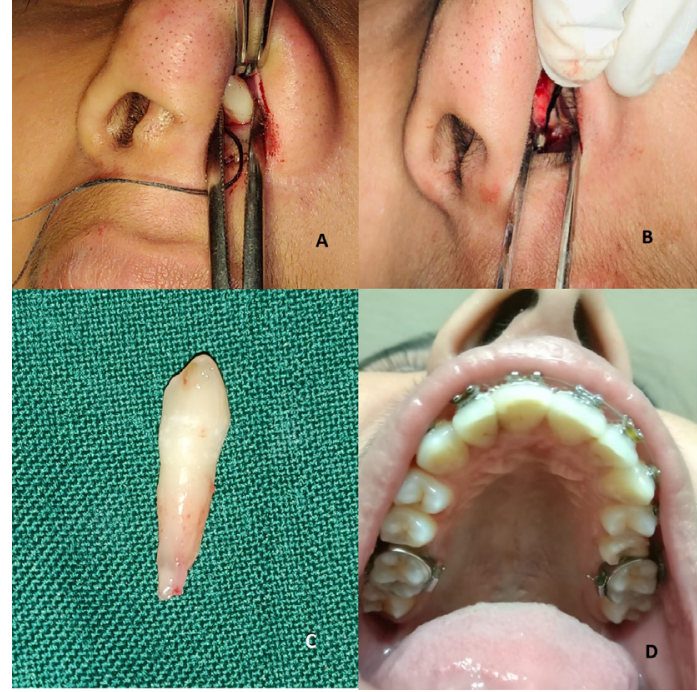

Figure 2 (A) Extracting mesiodens through the left nostril. (B) Left nostril immediately after extraction of mesiodens. (C) Extracted intranasal mesiodens. (D) One-year post-op of the palatal region after uneventful healing.

extracted through nostrils as the greatest convexity of tooth was more towards the nasal end.

Adequate local anaesthesia was achieved by administering bilateral infraorbital nerve block along with multiple palatal and intranasal infiltrations. A gauze with a suture tie was then packed

Learning points

- Intranasal retained tooth can cause symptoms like facial pain, external nasal deformities, foulsmelling rhinorrhoea, recurrent epistaxis, nasal obstruction and oronasal fistulae.

- Since very limited number of cases are reported, a definite treatment plan has not been developed. Treatment plan for each case is different based on the placement of the retained teeth and a thorough investigation should be performed before attempting to remove the teeth.

- Complications of nasal teeth include intraoperative injury to the soft tissues of the nasal region, haemorrhage and aspiration of tooth during extraction. Postoperative complications that may occur are-nasoseptal perforation, naso-oral fistula, pain, postoperative infections and periodic nose bleeding from the extraction site. 
into the left nostril, posterior to the tip of the mesiodens. It was placed to prevent accidental posterior displacement of the luxated tooth into the pharynx, thereby preventing aspiration or swallowing of the mesiodens.

A full-thickness mucoperiosteal flap was raised palatally to gutter the palatal bone for access to the root of the tooth and a Couplands elevator was used to luxate the tooth. After achieving adequate luxation, maxillary bayonet root forceps were used to grasp the tooth through left nostrils. The slender and long beak of the forceps provided the required approach to the tooth, which aided in the successful extraction of the mesiodens, and haemostasis was achieved (figure 2). The palatal flap was sutured back using simple interrupted sutures interdentally, following which, a gauze pack was placed in the nostril for a period of 24 hours. Cefpodoxime $200 \mathrm{mg}$ two times per day post procedure was prescribed for 5 days, and was also advised steam inhalation a week before and after the surgery. Postoperative healing was uneventful, and thus, no nasal decongestants were given. Saline douches were performed once on the third postoperative day.

The patient was recalled after 7 days for suture removal. The intranasal wound was evaluated and healing was found satisfactory. The patient was followed up for 1 year post procedure and she reported improved breathing efficiency and likewise decrease in the frequency of rhinitis and sinusitis postoperatively.

Contributors MM: Conception and design, acquisition of data or analysis and interpretation of data. Drafting the article or revising it critically for important intellectual content. Final approval of the version published. PS: Performed the clinical case and follow-up. Conception and design. Final approval of the version published. VJV: Acquisition of data or analysis and interpretation of data. Final approval of the version published. RK: Acquisition of data or analysis and interpretation of data. Final approval of the version published.

Funding The authors have not declared a specific grant for this research from any funding agency in the public, commercial or not-for-profit sectors.

Competing interests None declared.

Patient consent for publication Obtained.

Provenance and peer review Not commissioned; externally peer-reviewed.

\section{REFERENCES}

1 Nastri AL, Smith AC. The nasal tooth. Case report. Aust Dent J 1996;41:176-7.

2 Chen A, Huang J-K, Cheng S-J, et al. Nasal teeth: report of three cases. AJNR Am J Neuroradiol 2002;23:671-3.

3 Medeiros S, Gomide MR, Costa B. Prevalence of palate-The cleft palate. Craniofacial Journal 2000;37:271-3.

Copyright 2020 BMJ Publishing Group. All rights reserved. For permission to reuse any of this content visit

https://www.bmj.com/company/products-services/rights-and-licensing/permissions/

BMJ Case Report Fellows may re-use this article for personal use and teaching without any further permission.

Become a Fellow of BMJ Case Reports today and you can:

- Submit as many cases as you like

- Enjoy fast sympathetic peer review and rapid publication of accepted articles

- Access all the published articles

Re-use any of the published material for personal use and teaching without further permission

Customer Service

If you have any further queries about your subscription, please contact our customer services team on +44 (0) 2071111105 or via email at support@bmj.com.

Visit casereports.bmj.com for more articles like this and to become a Fellow 